\title{
Restructuring and Sustainability-Corporate Strategy of Commercial Bank in Thailand: A Siam Commercial Bank
}

\author{
Boriboon Pinprayong, Winai Wongsurawat \\ Asian Institute of Technology, Pathumthani, Thailand
}

\begin{abstract}
This article presents a case study of the Siam Commercial Bank (SCB) by investigating why and how SCB implemented organizational restructuring during the uncertain economic environment, and gives an overview of the Thai commercial bank industry. This article presents and discusses SCB's strategy implementation in its organization during 1997-2010. This case study is aimed to provide some guidelines for other companies in developing and in choosing strategies for their business sustainability in the global change, and in choosing the implementation of their organization structure for competitive markets.
\end{abstract}

Keywords: business sustainability, organizational restructuring, corporate strategy, banking, Thailand

\section{Introduction}

During 1997-2010, the Thai economy faced a number of challenges arising from the global economic slowdown, political uncertainties, and Thai baht appreciation. The result directly affected the Thai financial and banking industry. The first alternative for Thai businesses operating in the turbulent economic situations with higher level of market competition was to formulate new corporate strategy to implement their business plan adjustment and organizational restructuring.

Thus, this article aims to investigate the SCB's business situation during 1997-2010 by focusing on corporate strategy, organizational restructuring, control and measurement system, and corporate performance. Motivation to study this topic includes the following: none of the previous studies investigates the linkage between strategy, restructuring, and implementation on corporate performance, and very few studies have been conducted on strategy implementation in banking industry. The objectives specified to identify SCB's strategies for organizational restructuring and policies both in short term and long term for achieving their business objectives, and identify the factors which impact the bank’s corporate performance.

\section{The Evolution of Banking Industry in Thailand}

Before financial crisis in 1997, most commercial banks in Thailand never changed their corporate strategies because they were family businesses. During the financial crisis in 1997, Thai banks' business performance was at its worst, due to financial problems, leading to the growth of non-performance loans (NPL). In order to sustain Thai commercial bank industry and Thai economy, Thai government and bank of Thailand (BOT) changed the regulation of Thai commercial banks' shareholders by eliminating foreign investment

Boriboon Pinprayong, D.B.A. Candidate, School of Management, Asian Institute of Technology.

Winai Wongsurawat, Assistant Professor, School of Management, Asian Institute of Technology.

Correspondence concerning this article should be addressed to Boriboon Pinprayong, P.O. Box 4, Klong Luang, Pathumthani, 12120, Thaialnd. E-mail: boriboon60@gmail.com. 
barriers and allowed the foreign investment groups to hold up to $100 \%$ of Thai banks' shares. Since 1999, the foreign investment groups and offshore funds continued to acquire most Thai commercial banks by using takeover strategy and majority shareholder. This resulted in changes of the structure of shareholders and competition in the Thai banking market, and directly affected SCB's business and market share because the foreign investment groups had the financial strength, technical knowledge, and financial innovation to service their customers.

Overall, Thai commercial banking industry had high opportunity to create business performance because Thai market had large scale of retail group and the strength of the Thai economic structure can drive the Thai banking industry growth.

\section{SCB Company Background}

The Siam Commercial Bank (SCB) established in January 1906 in the reign of King Rama V as the first local commercial bank in Thailand. The bank had been listed on the Stock Exchange of Thailand (SET) since 1976. SCB was one of Thai commercial banks which were hit by the financial crisis which put the bank on the verge of bankruptcy. During 1997-2010, the bank, by top management level had continually implemented the business strategies with restructuring strategies by relating the global and the Thai economies in order to sustain its business in the economic slowdown, expand business in economic growth, and build business opportunity.

In order to explain SCB's employees to understand why SCB continued to implement its organizational restructuring, Dr. Vichit Suraphongchai, SCB's Chairman of the Executive Committee gave a speech in the SCB's forum that:

The change program is the project to change ourselves and the project will build the future of SCB. Someone asked whether SCB can stop this project, the answer is that we cannot stop this project. We must continue to change in order to sustain our bank Change is natural. Change is necessary. Change is our future, and we must continue to change our bank. (Pinprayong, 2011, p. 48)

According to the result of the Bank business sustainability, SCB flourished to the highest market capitalization among Thai Financial Institutions, the leadership bank in terms of number of branches, ATMs, market capitalization, and market share in banking market. In 2010, it had more than 1,000 branches and more than 8,000 ATMs in Thailand.

\section{Literature Review}

This section reviews the findings of previous relevant studies on corporate strategy, organizational restructuring, control and measurement system, and corporate performance.

\section{Corporate Strategy}

Corporate strategy is defined as the direction of an organization takes with the objective of achieving business success in the long term and short term including corporate vision, mission, goal, and SWOT analysis. The formulation of corporate strategy involves establishing the purpose and scope of the organization's activities and the nature of the business it is in, taking the environment in which it operates, its position in the marketplace, and the competition it faces into consideration. The role of corporate strategy is to provide business frame related to corporate situation, economy situations, external factors, internal factors, and business processes. The business frame had flexibility based on corporate situation, and to be clarity based on business goals for all business units to be implementing on the next business steps. When are companies likely to change 
their corporate strategy? Most companies have changed their corporate strategy depending on business performance during on the decline stage, bad management, and declining business ranking. Bivainis and Tomosiunas (2004) proposed that the management of enterprises' corporate restructuring were restructured by ensuring the effective utilization of the human, financial and material resources relevant strategy property, increasing the effectiveness of the management of the enterprise independent business units.

\section{Organizational Restructuring}

Organizational restructuring has been used to eliminate weaknesses in a firm and develop a strong organization. Boeker (1989) explained that strategies of organizations are likely to change following: the identification of serious problem, or in the face of declining performance. Lewis (1994) asserted that organization change related between culture, behavior, and organizational performance. Weller (1995) asserted that in the private sector, restructuring has a somewhat different connotation service, or sometimes to remain solvent and stay in business. Measures most used are either a substantial restructuring of the organization's production system or the use of downsizing, personnel lay-offs or hiring freezes.

Most root cause for implementation of organizational restructuring can be classified in five factors such as: (1) change in innovation in products, technology, materials, work processes, organizational structure, and organizational culture; (2) new and shifting markets; (3) action of global competitors, workforce value demand, and diversity; (4) regulatory and ethical constraints from the environment; and (5) individual development and transition. Lewin and Johnston (1996) found that the firm implemented organizational restructuring focused on organization structure and management process based on technology change, global competition and the emergence of a knowledge-based economy.

\section{Control and Measurement System}

Measurement system is the basis through which it is possible to control, evaluate, and improve process. In order for restructuring to achieve goals, the control and measurement system is used to evaluate and analyze the result or situation of organizational restructuring by holding key performance indicator (KPI), business best practices, world class standard such as organization performance, individual performance, customer satisfaction, and etc.. Taticchi, Tonelli, and Cagnazzo (2009) proposed performance measurement system to evaluate the quality of business framework by analyzing strategy, alignment, market, product, and leverages. In finance and banking industry, the security and safety system are important for building customers reliability. They can use the same control and measurement models as industrial/manufacturing sector. From the financial crisis, the new concept for banking control and measurement included fraud control and risk management in the Bank's standard.

\section{Corporate Performance}

Corporate performance can be evaluated, measured, and analyzed of the overall efficiency of organizational restructuring which reflects in high performance organization, growth rate, revenues and profits, growth in market share and market capitalization, employee job satisfaction, employee engagement, operation cost reduction, customer satisfaction, employee engagement, leader in product innovation, business process improvement, organizational citizenship behavior, and productivity delivery. In addition, the result of corporate performance which shows bad results, feedback, or complaint can give feedback to all the responsible authorities. Ferguson and Reio (2010) asserted that companies measured their corporate performance into two perspectives-financial performance and business performance. To sum up, the corporate performance 
presented the efficiency and effectiveness of firms by measuring and evaluating performance in part of finance, employee, business, and organization.

\section{Corporate Strategy and Corporate Performance}

The role of corporate strategy is to provide business frame related to corporate situation, economy situations, external factors, internal factors, and business processes. The business frame has flexibility based on corporate situation, and to be clarity based on business goals for all business units to be implemented on the next business steps. Mellat-Parast and Digman (2007) defined that quality management had been recognized as a comprehensive management paradigm for enhancing organizational performance and competitiveness. Since the corporate strategy is an important role in firm. In order to analyze the relationship between corporate strategy and corporate performance, this article sets assumption to test both variables. The following assumption was tested:

$\mathrm{H}_{1}$ : Corporate strategy differences in SCB will significantly affect corporate performance.

\section{Organizational Strategy and Corporate Performance}

The objectives of organizational restructuring can be concluded that it could change work process, organizational structure and organizational culture, reduce expenses, enhance competition in the business world, and develop organization in short period of time and for rapid organizational development as well as to motivate employees. Carroll and Wagar (2010) explained that organizational restructuring caused organizational engagement, business change, improving work processes and work design, employee commitment and satisfaction, employee development, and workplace performance improvement. In order to analyze the relationship between corporate strategy and corporate performance, this article sets assumption to test both variables. The following assumption was tested:

$\mathrm{H}_{2}$ : Organizational restructuring differences in SCB will significantly affect corporate performance.

\section{Control and Measurement System and Corporate Performance}

Control and measurement system is used to discover the quality and quantity of the result of implementation to ensure success in corporate goals. Amaratunga and Baldry (2003) argued that a performance measurement system may contribute to better goal attainment by an organization. It had been widely accepted that measurement could contribute to more effective control through giving insights. For the investigation of the relationship between control and measurement system and corporate performance, this article sets assumption to test both variables. The following assumption was tested:

$\mathrm{H}_{3}$ : Control and measurement system differences in SCB will significantly affect corporate performance.

\section{The Methodology and Model}

\section{Research Design}

This article used a two-stage methodology with a qualitative research-grounded theory, and quantitative research method in data collection which collected 291 samples from SCB manager level from 108 managers at HO, and 893 branch mangers by Taro Yamane’ method. In-depth interview used to collect the primary data and then a questionnaire survey is conducted with the same group of interviewees or respondents. For interview questions, this article used six open-ended questions for in-depth interviews of SCB's managers. The following questions were included in the questionnaires:

(1) What is the worst economic/financial situation your bank and your unit have ever had to deal with? 
(2) What internal factors, do you think, have an impact or influence on the performance of organizational restructuring in your company and your unit?

(3) Are there any conditions or situations in the external environment has impact on or influence the change process?

(4) What do you think of the high competition in the banking market between Thai banks and multinational banks? And what business method and strategy do you choose in a competition?

(5) Do you agree that the result of organizational restructuring will help boost your business? Yes/No, why?

(6) What do you think of your bank’s organizational restructuring after the financial crisis in 1997 ?

\section{Data Collection and Data Analysis}

This article applied grounded theory method in data collection which involved in-depth interview and open-ended questionnaire survey by scoping individual sample respondents, and analyzing secondary data. The use of both in-depth interviews and questionnaires can be considered useful in maximizing the strengths and minimizing the weaknesses of both techniques to ensure that the findings are more reliability. Table 1 outlines the result of the reliability on the survey items. According to the internal consistency and reliability of the result of the survey data, this article used Cronbach's coefficient alpha to test all data of the survey. The overall of the average of the reliability coefficient alpha of the surveys data indicate an alpha of 0.8677 .

Table 1

The Reliability Results for Each Variable

\begin{tabular}{llll}
\hline Variable & No. of case & No. of term & Reliability \\
\hline Corporate strategy & 291 & 16 & 0.8618 \\
Organizational restructuring & 291 & 34 & 0.8888 \\
Control and measurement system & 291 & 14 & 0.8510 \\
Corporate performance & 291 & 52 & 0.8693 \\
\hline
\end{tabular}

Note. Source: Pinprayong (2011).

\section{The Discussion and Findings}

The discussion and findings of this article could attest and confirm the objectives of study, and assigned that corporate strategy, organizational restructuring, and control and measurement system were independent variables, while corporate performance was dependent variable. The following paragraphs discuss the findings from the questionnaire survey in-depth interviews and the secondary data.

\section{Relationship Between Corporate Strategy, Organizational Restructuring, Control and Measurement System, and Corporate Performance}

In order to find factors influencing SCB business performance, this article used spearman correlation, one-way ANOVA, and $\rho=<0.05$ to analyze the relationship among independent variables and dependent variable specified in the Bank's organizational restructuring of business performance.

The result of spearman correlation testing showed in Table 2. The independent variables and the dependent variable showed high score of the correlation coefficient, and all variables were highly correlated. It meant that corporate strategy, organizational restructuring, and control and measurement system were significantly affected corporate performance. Furthermore, corporate strategy was significantly affected by 
organizational restructuring, and control and measurement system also.

Table 3 showed that SCB's corporate strategy, organizational restructuring, and control and measurement system were found to be significantly developed and changed the bank's corporate performance by showing positive coefficients of all sources, all with $\rho<0.05$. These mean that $\mathrm{H}_{1}, \mathrm{H}_{2}$, and $\mathrm{H}_{3}$ were proven valid.

Table 2

Correlation Matrix Between All Variables of SCB Business Performance

\begin{tabular}{lllll}
\hline Variables & 1 & 3 & 4 & 5 \\
\hline 1. Corporate strategy & 1.000 & & & \\
2. Organizational restructuring & $0.752^{* *}$ & 1.000 & & \\
3. Control and measurement system & $0.801^{* *}$ & $0.493^{* *}$ & 1.000 & \\
4. Corporate performance & $0.714^{* *}$ & $0.503^{* *}$ & $0.685^{* *}$ & 1.000 \\
\hline
\end{tabular}

Notes. $^{* *}$ : Correlation is significant at the 0.01 level (2-tailed); Source: Pinprayong (2011).

Table 3

One-way ANOVA for Corporate Strategy, Organizational Restructuring, and Control and Measurement System to Corporate Performance

\begin{tabular}{lllllll}
\hline Sources & $N$ & Sum of squares & $d f$ & Mean square & $F$ & Sig \\
\hline Corporate strategy & 291 & 75.573 & 2 & 37.786 & 145.638 & 0.000 \\
Organizational restructuring & 291 & 27.393 & 2 & 13.697 & 41.883 & 0.000 \\
Control and measurement system & 291 & 27.962 & 2 & 13.981 & 44.362 & 0.000 \\
\hline
\end{tabular}

Note. Source: Pinprayong (2011).

Based on factors influencing SCB business performance, SCB was able to use its corporate strategy to implement its organizational restructuring, and simultaneously used control and measurement system for managing its corporate performance.

\section{The Finding of SCB's Strategies of Business Sustainability}

In order to clearly investigate what SCB strategies and tactics choose to retain its business in each economic situations, this article decides to analyze the result of SCB's primary data and secondary data during 1997-2010.

The economic recession in 1997-1999. After the Asian financial crisis 1997, SCB had a lot of internal problems as cash flow problem, business performance, capital reduction, etc.. In order to sustain SCB's financial system, the bank decided to propose the early retirement program by offering pension plan which depended on the calculation on the basis of length of service and the amount of last pay received. Any employees are eligible to join this program. As a consequence of SCB's financial problem due to wrong business management, most of the top management team members resigned from SCB. Also, the bank closed some branches, and tried to stop the bank's NPL. In addition, from wrong investment, SCB sold non-core bank business sectors such as entertainment, construction, real estate, transportation, communication, etc.. In 1999, the bank succeeded in participating in the government's Tier 1 Capital Support Program, and increased its new capital. Kawai and Takayasu (2001) explained that the objective of the Tier 1 Capital Support Program was to encourage recapitalization of Thai commercial banks and finance companies, thereby, restoring and maintaining their solvency. As a result, the bank had a strong capital base, and it was the first bank to meet 100 percent mandatory provisional requirement. In order to plan to operate its business in 2000, the bank set a new 
corporate policy by increasing the efficiency of internal audit and control, developing the risk management system, reviewing business process, and managing NPL reduction. Meanwhile, all SCB's competitors stopped expanding their business, and stopped their services in some business areas because they had several problems, and their capital did not support the 100 percent of the loan-loss provision. As a result, in the second half of 1999, SCB started to develop its business for business expansion plan in 2000.

In brief, during this period, SCB's strategies had emphasized cost reduction strategies and developed a strong capital base by implementing several strategies, namely, (1) early retirement program (lay-off strategy); (2) changes taking place at the top management level; (3) closing low profit branches or loss-making branches; (4) selling non-core businesses; (5) reducing cost operations; (6) control and manage NPL; and (7) raising capital.

The economic renewal in 2000-2002. During this period, the Thai economy grew 4.5 percent in 1999. In the economic renewal, SCB emphasized its organizational restructuring based on building the strength of the bank's business. In 2000, SCB continued to rapidly expand its business because the bank expected the Thai economy to boom again. Edwards, Woodall, and Welchman (1996) explained that corporations emphasized business recovery in crisis by restructuring organization and management which led structure and culture to be changed. In 2001, SCB established a new unit under the name of "Change Program Project" to manage and control the implementation of the first phase of the organizational restructuring only, in order to ensure the successful implementation of organizational restructuring. Furthermore, this new unit had developed strategy implementation and evaluated the result of restructuring. Based on customer satisfaction, the bank changed its culture from "customer walk-in" to access banking services to the bank's employees approaching customers. As a result, SCB started to expand its business aiming at the new target groups, and simultaneously implemented retail distributions. Pollitt (2006) asserted that corporate culture changed was able to support the business advantages in terms of strategy, competition, customer relationship, and employees' responsibility.

One of the branch managers working in Bangkok's vicinity area who were in favour of SCB's organizational restructuring strategies explained that:

Organizational restructuring is the best strategy. SCB can adapt itself in the present situation by restructuring organization and reprocessing work. The results of restructuring enable SCB success in running business in the crisis time, economic change and the future. Furthermore, the bank can transform business threats into business opportunities. Consequently, SCB had many banking products to support customer requirement and increase customers' volumes. In addition, rewards from other financial institute given to the bank can guarantee success in its business performance. (Pinprayong, 2011, p. 73)

Meanwhile, all SCB's major competitors were still fixing their NPL problems, and delayed their business expansion. SCB made a new appearance by creating SCB brand together with redesigning physical branches based on the purple colour. Douglas (2001) proposed that the strong brand was able to create a competitive advantage in marketplace, and strengthening customer loyalty. In 2002, to continually expand new retail group and volumes of loans, increase the bank's loan-loss coverage ratio, and control its NPL volumes, SCB chose to reserve to fully accommodate any potential deterioration of Problem Classified Loans by setting aside a huge provision for loan-loss of about 24.8 billion baht. As a result, the bank reported a net loss of 12.5 billion baht but it succeeded to expand its loans in the short-term and long-term.

In the economic renewal period, SCB placed importance on its organizational restructuring by establishing new office whose main responsibility was to monitor and control the implementation of organizational 
restructuring strategy. Furthermore, in order to sustain SCB's business, the bank aimed to build the strength of the Bank's business by implementing strategies, namely, (1) developing new culture (change culture); (2) re-building brand and branch redesign; (3) focusing on the retail group; (4) expanding retail distribution; (5) controlling NPL volumes; (6) controlling cost and budget; and (7) restructuring its organization. As a result, in 2000, the Bank started to sustain its business by showing its net profits, and several years later, the Bank continued to achieve its business expansion by increasing its revenues, market share, customer base, and managing its strong capital.

The economic growth in 2003-2006. During 2003-2006, the Thai economy continued to grow by an average of 5.65 percent. As a result, all SCB's major competitors began to expand their businesses which led to high competition in the Banking market. Thus, SCB emphasized its protection and prevention business and continual organizational restructuring based on differentiation strategy. Chi (2010) explained that in order to increase competitiveness, corporations chose to implement differentiation strategy and/or cost leadership strategy. In 2003, the Bank achieved its branch network expansion, creation of solid positioning of market share for future growth, and the revitalization of its profitability. As a result, the Bank could protect its market share and prevent its competitors' business expansion. In 2004, with the successful organizational restructuring in the first phase, the Bank started to implement the next phase of organizational restructuring by focusing on business growth, human resources development, and the premier universal bank model. Furthermore, SCB replaced new core bank system to support customer volumes more than 10 million accounts. In 2005, the Bank started to change its branch services to the premier universal bank concept, and kept its customer service standard based on the one-standard of service by setting its business performance standards with respect to service quality and employee performance according to the World Class Standard, Customer Engagement (CE), and Customer Satisfaction Score (CSS). Moreover, in 2005, the Bank started to pay a dividend to shareholders, and in 2006, the Bank held the second highest market capitalization among the Thai Financial Institutions, and the third biggest bank in Thailand.

With the strong SCB's capital, the Bank investigated Asian market's potential, and found that Asian markets could grow their performance with a large scale of customers and big business gaps in markets. The Bank invested its money in Asian markets such as in Cambodia by using owner strategy in 2002-2003, in Vietnam by using joint venture strategy and providing banking know-how and capital in 2004, and in the People's Republic of China by using alliance strategy in 2005 because this strategy was able to save cost investment.

During the economic growth period, the successful organizational restructuring had led to the decision of the Bank to continually restructure based on the Bank's strategies for business recovery and business expansion by implementing various strategies, namely, (1) restructuring its organization; (2) changing branch banking concept; (3) recognizing the premier universal bank; (4) expanding business to SME sector and large industry; (5) continuing the launch of new banking products; (6) increasing customer loans; (7) recruiting employees; (8) replacing and implementing new core bank system and new business process; (9) expanding investment and service in other regions; and (10) developing human resources. As a result, the Bank continued to increase its revenue and market capitalization.

The economic decline in 2007-2010. During this period, Thai economy continued to decline due to the Thai political instability, and the global economic uncertainty. During this period, other banks quickly expanded their businesses because they believed that the Thai economy will rebound soon as some of them 
have already lost their market share to SCB. Especially, in 2009, the Thai economy grew -2.3 percent. In order to sustain SCB's business during the Thai economic decline period, the Bank had been continuously restructuring its organization based on its strategies of the business expansion and customer retention. In 2007, SCB's organizational restructuring emphasized business expansion by continuing transformation of the Bank's competitiveness and franchise values. As a result, the Bank succeeded to gain market share in the SMEs and hire-purchase businesses. While the Bank's competitors quickly expanded their businesses because they believed that the Thai economy will rebound soon and they already lost their market share to SCB.

In 2008, the Thai economy had been strongly affected from the global economic fluctuation. For business performance and market share, SCB still expanded its business, and simultaneously adjusted its business risk level. Regarding the Bank's solid capital base, SCB implemented BASEL II project for computing its capital adequacy ratio. As a result, in 2008, the Bank showed again its net profits at baht 21.4 billion a 23.4 percent increase. It was the highest in SCB's history.

In the following year, 2009, the Thai economy declined again which affected the SCB's business performance. Thus, the Bank's organizational restructuring was undertaken with the emphasis on two strategies, namely, costs and budgets reduction, and business expansion. Based on costs and budgets reduction strategy, the Bank had implemented the shared service strategy for SCB's subsidiary companies by offering IT, legal, financial system, infrastructure, risk management and control system, internal audit, HR, and communication. As a result, the Bank was able to reduce its costs and budget. Moreover, the Bank had increased new customer groups, and expanded new market from SCB's subsidiary companies' customer base. Furthermore, the Bank assigned cost reduction strategies for $\mathrm{HO}$ offices and business expansion strategies for all branches. For business expansion strategy, the Bank aimed to maintain its customer base, and expand market share in the blue-chip, public sector segments, and mortgage. Moreover, during 2009-2010, SCB emphasized employee’s cost reduction by stooping recruitment project, and instead, it proposed employee development project. The result of the implementation of costs and budgets reduction and business expansion led to the Bank's net profits at baht 20.8 billion.

In 2010, the Thai banking market continued its fierce competition. SCB started to offer customer benefits in terms of special interest rates, credit line expansion, and long term loan agreement. As a result, SCB showed its net profit in 2010 at baht 24.2 billion.

Besides, the economic decline period had experienced a lot of unemployed people and increased NPL. Based on SCB's business sustainability, the Bank emphasized the NPL reduction, and retained the customers' loans. The Bank proposed its business participation policy on giving consultation to customers in financial system and suggested new markets in the domestic and the international markets.

According to the economic decline period, the Bank emphasized its organizational restructuring to implement its business maintenance and its business expansion for business sustainability based on several activities, namely, (1) maintaining the customer loyalty; (2) increasing services and banking products quality; (3) expanding new market and new customer groups; (4) maintaining employees and delaying recruitment; (5) controlling costs and budgets; (6) maintaining SCB brand; (7) implementing shared service strategy; and (8) continual implementing organizational restructuring. Consequently, during 2007-2009, even though, Thailand's GDP continued to decrease, but SCB's annual reports still show its net profit growth, return on equity (ROE) growth, return on asset (ROA) growth, and NPL reduction, as shown in Table 4, and during 2007-2009, the Bank achieved the highest market capitalization among Thai Financial Institutions. 
Overall SCB's business sustainability had been achieved. The Bank is able to operate its business in the economic uncertainty by implementing continuously its organizational restructuring with various business strategies.

Table 4

Comparison Between SCB’s Performance and the Thai Economy During 1996-2010

\begin{tabular}{|c|c|c|c|c|c|c|c|c|}
\hline \multirow{3}{*}{ Year } & \multirow{3}{*}{$\begin{array}{l}\text { \% of Thailand's } \\
\text { GDP }\end{array}$} & \multicolumn{5}{|c|}{ SCB's financial performance } & \multicolumn{2}{|c|}{ SCB's structure } \\
\hline & & \multicolumn{2}{|c|}{ Billion of baht } & \multirow{2}{*}{$\%$ of ROE } & \multirow{2}{*}{$\%$ of ROA } & \multirow{2}{*}{$\%$ of NPL } & \multirow{2}{*}{$\begin{array}{l}\text { Total } \\
\text { branches }\end{array}$} & \multirow{2}{*}{ Total ATMs } \\
\hline & & Total asset & Net profit (loss) & & & & & \\
\hline 1996 & 5.9 & 541.23 & 9.0 & 23.73 & 1.81 & 1.5 & 441 & 796 \\
\hline 1997 & $(1.4)$ & 717.16 & 3.2 & 7.75 & 0.51 & 3.3 & 463 & 827 \\
\hline 1998 & $(10.5)$ & 702.84 & $(15.6)$ & $(40.6)$ & $(2.2)$ & 37.1 & 489 & 844 \\
\hline 1999 & 4.5 & 683.45 & $(48.7)$ & (79.9) & $(5.1)$ & 24.2 & 496 & 851 \\
\hline 2000 & 4.8 & 712.19 & 3.5 & 6.2 & 0.5 & 19.2 & 476 & 872 \\
\hline 2001 & 2.2 & 711.89 & 9.2 & 0.7 & 0.1 & 30.8 & 477 & 894 \\
\hline 2002 & 5.3 & 667.22 & $(12.5)$ & (21.9) & (1.8) & 24.2 & 483 & 1,083 \\
\hline 2003 & 7.1 & 736.26 & 12.5 & 19.5 & 1.8 & 17.5 & 501 & 1,317 \\
\hline 2004 & 6.3 & 754.83 & 18.5 & 23.1 & 2.4 & 13.2 & 562 & 1,959 \\
\hline 2005 & 4.5 & 807.75 & 18.9 & 20.8 & 2.4 & 9.3 & 692 & 2,803 \\
\hline 2006 & 5.1 & 982.63 & 13.3 & 13.4 & 1.4 & 7.8 & 793 & 3,828 \\
\hline 2007 & 4.8 & $1,112.82$ & 17.4 & 16.5 & 1.6 & 6.1 & 874 & 4,833 \\
\hline 2008 & 2.6 & $1,241.64$ & 21.4 & 18.0 & 1.8 & 5.1 & 949 & 6,030 \\
\hline 2009 & (2.3) & $1,294.05$ & 20.8 & 15.5 & 1.6 & 4.4 & 987 & 7,129 \\
\hline 2010 & 7.8 & $1,476.76$ & 24.2 & 16.4 & 1.7 & 3.3 & 1,009 & 8,006 \\
\hline
\end{tabular}

Note. Source: From BOT and SCB Annual report during 1996-2010.

\section{Conclusions}

The result of the successful bank business sustainability had been clearly due to the organizational restructuring with business expansion plan. As a result, SCB could achieve to increase its business efficiency to improve revenue and profit growth, market capitalization growth, customer satisfaction, and competitiveness. During 2003-2009, the bank had continually generated its benefits, and constantly approved a dividend payment starting in 2005. Dr. Vichit Suraphongchai, SCB's Chairman of the Executive Committee noted in annual report 2008 that:

Some eight years ago we commenced our transformation journey through our Change Program (organizational restructuring) in order to reposition our franchise by improving our competitiveness and core profitability in a fast evolving landscape. While the journey continues, the increasing numbers of awards have been achieved by our Bank. (SCB Annual report 2008, p. 4)

In addition, this article concluded SCB's successful organizational restructuring and corporate performance based on the four key factors such as, first, the corporate strategy and policy had been proposed and distinctively implemented for the organizational restructuring. Second, the top management level had been involved in the organizational restructuring program. Third, the plan of the organizational restructuring was aligned to the bank's business plan, and fourth, the bank had established a separate unit called "Change Program Management Office” to manage the organizational restructuring, and approve the organizational restructuring under "Change Program Steering Committee”. 


\section{References}

Amaratunga, D, \& Baldry, D. (2003). A conceptual framework to measure facilities management performance. Property management, 21(2), 171-189.

Bank of Thailand. (1998-2010). Annual Economic Report. Bangkok: Thailand.

Bivainis, J., \& Tomosiunas, A. (2004). Strategic solutions for corporate restructuring. International Journal of Strategic Property Management, 8(1), 45-55.

Boeker, W. (1989). Strategy change: The effects of founding and history. Academy of Management Journal, 32(3), $489-515$.

Carroll, R. W., \& Wagar, H. T. (2010). Is there e relationship between information technology adoption and human resource management? Journal of Small Business and Enterprise Development, 17(2), 218-229.

Chi, T. (2010). Corporate competitive strategies in a transitional manufacturing industry: An empirical study. Management Decision, 48(6), 976-995.

Douglas, S. (2001). Executive insights; integrating branding strategy across markets; building international brand architecture. Journal of International Marketing, 9(2), 97-115.

Edwards, C., Woodall, J., \& Welchman, R. (1996). Organizational change and women managers careers: The restructuring of disadvantage? Employee Relations, 18(5), 25-45.

Ferguson, L. K., \& Reio, G. T. (2010). Human resource management system and firm performance. Journal of Management Development, 29(5), 471-494.

Huang, T. C. (2001). The effects of linkage between business and human resource management strategies. Personnel Review, 30(2), 132-151.

Kawai, M., \& Takayasu, K. (2001). The economic crisis and banking sector restructuring in Thailand. Center for Pacific Business Studies, Sakura Institute of Research, 37-103.

Lewin, J. E., \& Johnston, W. J. (1996). The effects of organizational restructuring on industrial buying behavior: 1990 and beyond. Journal of Business \& Industrial Marketing, 11(6), 93-111.

Lewis, S. D. (1994). Organizational change: Relational between reactions, behavior and organizational performance. Journal of Organization Change Management, 7(5), 41-55.

Mellat-Parast, M., \& Digman, A. L. (2007). A framework for quality management practice in strategy alliance. Management Decision, 45(4), 802-818.

Pettigrew, A., \& Massini, S. (2000). Innovative forms of organizing in Europe and Japan. European Management Journal, 18(3), 259-273.

Pinprayong, B. (2011). Corporate strategy, organizational restructuring, and corporate performance: A case of Siam Commercial Bank (Unpublished dissertation, School of Management, Asian Institute of Technology, Thailand).

Poblos, O. P., \& Lytras, D. M. (2008). Competencies and human resource management: Implications for organizational competitive advantage. Journal of Knowledge Management, 12(6), 48-55.

Pollitt, D. (2006). Continuous improvement safeguards factory's future at innovation film: Training program helps to change the organizational culture. Human Resource Management International Digest, 14(2), 15-18.

Siam Commercial Public Bank. (1997-2010). Annual report. Bangkok: Thailand.

Taticchi, P., Tonelli, F., \& Cagnazzo, L. (2009). A decomposition and hierarchical approach for business performance measurement and management. Measuring Business Excellence, 13(4), 47-57.

Weller, D. L. (1995). School restructuring and Downsizing: Using TQM to promote cost effectiveness. The TQM Magazine, 7(6), 11-16. 